\title{
Shifted effect of three years of the minimum temperature, rainfall and water deficit on the nuts yielding expression in Cocos nucifera L., Côte d'Ivoire
}

\begin{abstract}
To assess the shifted effect of the sic climatic variables on the further coconuts yielding expression, the modeling was investigated. The monthly coconuts yielding, maximum temperature, minimum temperature, temperature difference, average temperature, rainfall and water deficit were daily measured and recorded. The Anova and multiple linear regression were used. The monthly coconuts yielding in 2010 was greater than that of in 2013, confirming the decreasing trend of yielding. During the two years, out of the temperature difference, the five other climatic variables were not significantly varied, indicating their constancy. The minimum temperature, rainfall and water deficit variations from year 2010 accounted for $64.20 \%$ fluctuations of the monthly coconuts yielding from 2013. Thus, these three climatic variables significantly acted on the monthly coconut yielding variations expression. The linear equation which modeled the monthly coconuts yielding is written: Yielding $=-1436.11+1275.303$ *Tmin+49.437* Rain+31.476*Watdef. Nonetheless, it specifically applied to year 2010 and 2013 as well as 2011 and 2013. We cannot do of that general rule.
\end{abstract}

Keywords: climatic variables, linear equation, multiple linear regression, modeling monthly coconuts yielding
Volume 2 Issue 3 - 2018

\author{
Auguste Emmanuel Issali, ${ }^{1,2}$ Sylvain N'cho \\ Djoman, ${ }^{3}$ Sidibé Daouda, ${ }^{3}$ Allou Kouassi, ${ }^{1,4}$ \\ Abdourahamane Sangare, ${ }^{1,5}$ Adiko \\ Amoncho ${ }^{1,6}$ \\ 'Centre National de Recherche Agronomique, Côte d'Ivoire \\ ${ }^{2}$ Station de Recherche sur le cocotier Marc Delorme, Côte \\ d'Ivoire \\ ${ }^{3}$ Laboratoire de Génétique, Université Félix Houphouët Boigny, \\ Côte d'Ivoire \\ ${ }^{4}$ Direction de la Station de Recherche sur le palmier à huile, \\ Côte d'lvoire \\ ${ }^{5}$ Direction Générale Adjointe du CNRA, Côte d'Ivoire \\ ${ }^{6}$ Conseil Scientifique de la Direction Générale du CNRA pour \\ la Coopération Internationale, Côte d'Ivoire
}

\begin{abstract}
Correspondence: Auguste Emmanuel Issali, Forestry Engineer, Geneticist Plant Breeder at CNRA, (Centre National de Recherche Agronomique), Marc Delorme Coconut Research Station Port Bouët, 07 PO Box 13,Abidjan 07, Côte d'Ivoire, Email issaliemma@yahoo.com
\end{abstract}

Received: April II, 2018 | Published: May 29, 2018

\section{Introduction}

Cocos nucifera L., multi-purpose uses plant, is oleaginous and sugar crop of the Arecaceae. ${ }^{1}$ In Côte d'Ivoire, cultivated areas cover about 50,000 hectares for yielding about 330 million coconuts. The coconut crop supports 23,000 families essentially based on the coastal region. Moreover, the Marc Delorme Coconut Research Station (MDCRS) hosts the International Coconut Genebank for Africa and Indian Ocean (ICGAIO). It is one of the five genebanks managed by International Coconut Genetic Resources Network (COGENT) around the world. It provides seednuts not only to Africa and Indian Ocean countries, but also around the world. Out of such a mission, by-products from the research are marketed at local level. Hence, at the end of the coconuts harvest, the samples intended to the research are sent to the technology unit. This determines technological characteristics of different coconut compounds as well as oil content. The rest of yielding is sold to customers' CNRA (Centre National de Recherche Agronomique).

To date, out of some works such as those from Peiris et al., ${ }^{2}$ which modeled the yielding in coconut palm in India, informations about yielding modeling are scarce. Therefore, the factors predicting the yielding in Côte d'Ivoire are unknown. Indeed, it was noted a decreasing of the monthly and annual coconut yielding at the
MDCRS. In that light, we postulate that among the six climatic variables, namely the maximum temperature, minimum temperature, temperature difference, average temperature, rainfall and water deficit at least one could significantly determine the monthly coconuts yielding fluctuations. The knowledge of yielding prediction model could allow the incomes and yielding prediction to make profitable the coconut investment. The goal of work was to search for the equation which models the yielding fluctuations as a function of six climatic variables.

\section{Materials and methods}

\section{Plant material, data collection site and technical materials}

Data at field were collected daily at the MDCRS based on Port Bouët in Côte d'Ivoire from 2004 to 2013. They proceeded from harvested and scored coconuts. These were skinned monthly or bimonthly for need monitoring as a function varietal type. Three plant material types were used. These are tall and dwarf coconut ecotypes as well as the hybrid ones. The first two proceed from the ICGAIO located at the MDCRS. They are ex situ conserved at field for need research and development. The latter is constituted of tall $\mathrm{x}$ tall, dwarf $\mathrm{x}$ tall and dwarf $\mathrm{x}$ dwarf coconut hybrids in accordance with three 
coconut breeding ways. Indeed, dwarf ecotypes and dwarf $\mathrm{x}$ dwarf hybrids are harvested monthly, while the tall ecotypes, tall $\mathrm{x}$ tall and dwarf $x$ tall hybrids are harvested every two months. The experiments intended to research are put in place by plantation managing division. Beyond twelve or fifteen years, the research returns experiments to plantation managing division for by-products valuation. Seventy fields of the MDCRS provided data used here.

The technical materials consisted of sickle attached to the tip of a bamboo, rubber ribs, machetes, tractor-trailer, tool bag, registration notebook, permanent markers, ball point pens, dehusking stake. The harvest, grouping and collecting of ripe coconuts were done by team of four persons. The harvested coconuts were grouped by five. The registration team scored and recorded coconuts harvested by tree at field. These coconuts grouped were charged in trailer of tractor and conducted at collection area. On this one, in turn dehuskers dehusked and scored ripe fruits. The sale clerk collected the dehusked coconuts number by dehuskers and compared this one with the one recorded at field.

\section{Variables measurement}

The number of ripe fruits harvested was scored every day and recorded. At the end of each month, the person in charge of the plantation managing division added them to provide data that we used in your study.

\section{Data analysis methods}

The software's SPSS and Xlstat, versions 16.0 and 2007, respectively were used for statistical analyses. Collected data were subjected successively to Anova and multiple linear regression. The Anova incorporating means separation according to Newman-Keuls' test at $5 \%$ threshold as well as the backward elimination stepwise multiple regression technique were used.

\section{Results}

\section{Year effect on the monthly coconuts yielding and six climatic variables expression in 2010 and 2013}

Regarding, the monthly coconuts yielding, two distinct groups were evidenced. The first one constituted of year 2013 was characterized by low monthly coconuts yielding. The second one composed of year 2010 was marked by high monthly coconuts yielding. Dispersion around mean varied from 9.54 to $9.80 \%$ (Table 1).

For climatic variables, no significant difference was observed for two years of the study concerning maximum temperature, minimum temperature, average temperature, temperature differences, rainfall and water deficit. In contrast, the rainfall provided two homogeneous groups. First, composed of year 2013, was characterized by weak monthly rainfall. Second, consisted of year 2010, was distinguished by strong monthly rainfall. Variability around calculated mean fluctuated from 1.24 to 19.15 (Table 1).

Shifted effect of the minimum temperature, rainfall and water deficit from 2010 on the monthly coconut yielding variation expression from 2013

The backward elimination stepwise multiple regression technique showed that out of six climatic variables, only three namely minimum temperature, rainfall and water deficit triggered rough fall of the coefficient of determination namely $\mathrm{R}^{2}$. Therefore, the regression of the mature yielded fruits in 2013 on minimum temperature, rainfall and water deficit recorded in 2010 was significant. All of three proposed models of the regression were found to be significant. The second one was retained in the rest of the study. Indeed, the removal of the temperature differences in model 1 increased the coefficient of determination $\mathrm{R}^{2}$ of $0.10 \%$, instead of reducing it. This model explained $64.20 \%$ fluctuations minimum temperature, rainfall and water deficit (Table 2).

The linear function corresponding to the monthly coconuts yielding is spelt: Yielding $=-1436.11+1275.303 * \mathrm{Tmin}+49.437 *$ Rain $+31.476^{*}$ Watdef. This equation shows that the monthly coconuts yielding increases on average of 1275.303, when the minimum temperature increases of $1^{\circ} \mathrm{C}$, increases on average of 49.437 , when the rainfall increases of $1 \mathrm{~mm}$, increases on average of 31.476 , when the water deficit increases of $1 \mathrm{~mm}$. This yielding would be equal to -1436.11 if the minimum temperature, rainfall and water deficit was zero.

\section{Discussion}

The cumulative effect of the minimum temperature, rainfall and water deficit from 2010 on the subsequent yielding variation expression from 2013 was measured. In Sri Lanka, Peiris et al., ${ }^{2}$ showed that, $94 \%$ fluctuations yielding were due among other things to rainfall. In Côte d'Ivoire, Traoré Sékou ${ }^{3}$ revealed that the minimum temperature accounted for $65.14 \%$ variations monthly coconuts yielding. Our works displayed that, $64.20 \%$ variations monthly coconuts yielding from the year 2013 were attributable to the minimum temperature, rainfall and water deficit from the year 2010 .

The monthly coconuts yielding in the year 2010 was the highest (Table 1). Nonetheless, there is strong decreasing trend of the yielding in fields of the MDCRS since 2003. One of the reasons of this decreasing is the lack of chemical fertilisation in fields since fifteen years. Dassé, ${ }^{4}$ analysing monthly yielding from 2003 to 2009 , identified three yielding year classes. The third one namely 2009 was marked by low yielding. Likewise, our results showed that year 2013 was the least productive. It would be good to analyse deeply this decreasing trend to deduct general rule regarding yielding at the MDCRS.

During the year 2010, rainfall was the highest (Table 1). The annual pluviometric total was $2596.5 \mathrm{~mm}$, as against $1830.09 \mathrm{~mm}$ for decennial annual average pluviometric total from 2000 to $2009 .{ }^{5}$ Such increased gaps of rainfall level could be due to effects of climatic warming. Shifted effect of the minimum temperature, rainfall and water deficit from the year 2010 explained $64.20 \%$ fluctuations of monthly coconuts yielding from the year 2013 (Table 2). Hence, it would exist a significant shifted effect from 3 years between the minimum temperature, rainfall and water deficit and the monthly coconuts yielding. This effect is not direct, but shifted in the time. In the other words, the minimum temperature, rainfall and water deficit from a given year don't act on the coconut yielding from the same year. Thus, effects of the three aforementioned climatic variables were expressed three years later. Issali (2008) showed that somatic embryogenesis in Theobroma cacao increased three month after the increasing of the relative humidity. Tan \& Furtek ${ }^{6}$ reported in Theobroma cacao that the floral explants harvested and cultured at the beginning of the rainy season, especially after a period of prolonged dry season, acquired a high efficiency in somatic embryogenesis. In the same way, Allou ${ }^{7}$ showed that, in Côte d'Ivoire, the yielding 
in oil palm at 28th month is determined by the water deficit having prevailed 27 months earlier. However, we cannot do it as a general rule. Indeed, the tests achieved using data ranging from 2004 to 2013 did not provide a good fit namely $\mathrm{R}^{2}$. Only effects of three climatic variables from 2011 also were well-fitted in relation to those of the coconuts yielding from 2013. Nonetheless, in the two cases, the climatic variables namely rainfall and water deficit belong to linear model. Thus, the minimum temperature, rainfall and water deficit significantly determined the monthly coconuts yielding fluctuations.

Yielding $=-1436.11+1275.303 *$ Tmin $+49.437 *$ Rain $+31.476 *$ Watdef is the linear equation which models the fluctuations of the monthly coconut yielding. Peiris et al., ${ }^{2}$ proposed a model for coconut yielding including technology and rainfall. Issali et al., ${ }^{5}$ found an equation modeling the seednuts yielding proceeding from controlled pollinations using set fruits. In our equation, the regression coefficient associated with the minimum temperature is the highest. This shows the importance of this climatic variable. Indeed, it accounted for itself $61.70 \%$ variations of the monthly coconut yielding (Table 2 ). Its positive sign shows that it varies in the same sense than the monthly coconut yielding. Therefore, the years recording the highest minimum temperatures could provide high yielding. Nevertheless, we cannot do it as a general rule. ${ }^{8}$

Table I Classification of yearly means of the monthly coconuts yielding as a function of year based on parametric Student $t$ test

\begin{tabular}{|c|c|c|c|c|c|c|}
\hline Factor & $\begin{array}{l}\text { Dependent } \\
\text { variable }\end{array}$ & $\begin{array}{l}\text { Factor } \\
\text { variant }\end{array}$ & $\begin{array}{l}\text { Transformed } \\
\text { mean }\end{array}$ & CV (\%) & $\begin{array}{l}\text { Untransformed } \\
\text { mean }\end{array}$ & $\begin{array}{l}\text { Measurement } \\
\text { unit }\end{array}$ \\
\hline \multirow{14}{*}{ Year } & \multirow[t]{2}{*}{ Yielding } & 2013 & $416.310 \mathrm{a}$ & 9.8 & 173314.3 & fruits \\
\hline & & 2010 & $467.577 b$ & 9.54 & 218628.1 & fruits \\
\hline & \multirow[t]{2}{*}{ Tmax } & 2010 & $1.483 \mathrm{a}$ & 1.62 & 30.416 & ${ }^{\circ} \mathrm{C}$ \\
\hline & & 2013 & $1.483 \mathrm{a}$ & 1.64 & 30.416 & ${ }^{\circ} \mathrm{C}$ \\
\hline & \multirow[t]{2}{*}{ Tmin } & 2013 & $1.344 \mathrm{a}$ & 1.67 & 22.08 & ${ }^{\circ} \mathrm{C}$ \\
\hline & & 2010 & $1.355 \mathrm{a}$ & 1.24 & 22.667 & ${ }^{\circ} \mathrm{C}$ \\
\hline & \multirow[t]{2}{*}{ Tmoy } & 2013 & - & 4.93 & $18.0194 \mathrm{a}$ & ${ }^{\circ} \mathrm{C}$ \\
\hline & & 2010 & - & 4.5 & $18.2083 \mathrm{a}$ & ${ }^{\circ} \mathrm{C}$ \\
\hline & \multirow[t]{2}{*}{ Etm } & 2010 & - & 14.06 & $7.775 \mathrm{a}$ & ${ }^{\circ} \mathrm{C}$ \\
\hline & & 2013 & - & 13.79 & $8.358 \mathrm{~b}$ & ${ }^{\circ} \mathrm{C}$ \\
\hline & \multirow[t]{2}{*}{ Rain } & 2013 & $1.707 \mathrm{a}$ & 16.33 & 49.921 & $\mathrm{~mm}$ \\
\hline & & 2010 & $2.231 \mathrm{~b}$ & 15.08 & 170.177 & $\mathrm{~mm}$ \\
\hline & \multirow[t]{2}{*}{ Watdef } & 2010 & $0.431 \mathrm{a}$ & 185.575 & 2.698 & $\mathrm{~mm}$ \\
\hline & & 2013 & $1.085 \mathrm{a}$ & 19.15 & 12.151 & $\mathrm{~mm}$ \\
\hline
\end{tabular}

Legend: CV (\%), coefficient of variation; Untransformed mean, values were obtained squaring the transformed ones

Table 2 Effects of minimum temperature, rainfall and water deficit on the monthly coconuts production based on backward elimination stepwise multiple linear regression technique

\begin{tabular}{llllllll}
\hline Model* & Source & SS* & df* & MS* & F & P-value* & Adjusted R $\mathbf{~ ( \% ) * ~}^{*}$ \\
\hline 1 & Regression & 14128.9 & 4 & 3532.225 & & & \\
& Residual & 4187.376 & 7 & 598.197 & 5.905 & $0.021 \mathrm{a}$ & 64.1 \\
& Total & 18316.28 & 11 & & & & \\
2 & Regression & 13551.28 & 3 & 4517.094 & & & \\
& Residual & 4764.994 & 8 & 595.624 & 7.584 & $0.010 \mathrm{~b}$ & 64.2 \\
& Total & 18316.28 & 11 & & & & \\
& Regression & 12601.58 & 2 & 6300.788 & & & \\
& Residual & 5714.701 & 9 & 634.967 & 9.923 & $0.005 \mathrm{c}$ & 61.9 \\
& Total & 18316.28 & 11 & & & & \\
& Regression & 11931.25 & 1 & 11931.25 & & & \\
& Residual & 6385.027 & 10 & 638.503 & 18.686 & $0.002 \mathrm{~d}$ & 61.7 \\
& Total & 18316.28 & 11 & & & & \\
\hline
\end{tabular}

Legend: $\mathrm{df}^{*}$, degree of freedom; SS*, Sum of squares; MS*, Mean square; F*, Fisher-Snedecor statistics; p-value*, Calculated probability to compare with $5 \%$ significance level; a, Predictors: Constant, Watdef 2010, Etm 2010,Tmin 2010, Rain 2010. b. Predictors: Constant, Watdef 2010,Tmin2010, Rain20I0. c. Predictors: Constant,Watdef 2010,Tmin20 I0. d. Predictors: Constant,Tmin20 I0. e. Dependent Variable:Yielding2013;Adjusted R² (\%)* Coefficient of determination taking into account the number 


\section{Acknowledgements}

None.

\section{Conflict of interest}

There is no conflict of interest that prevents this publication.

\section{References}

1. Guyot M. Systématique des angiospermes: référence à la flore du Togo Edition financée par la Mission Française de Coopération et d'Action Culturelle de Lomé. Diffusion auprès de la bibliothèque de l'Université du Benin, Togo; 1992. p 174.

2. Peiris TSG, Hansen JW, Zubair L. Use of seasonal climate information to predict coconut production in Sri Lanka. Int J Climatol. 2008;28(1):103-110.

3. Traoré S. Etude de l'influence de quelques variables climatiques sur l'expression de la production de fruits matures chez le cocotier (Cocos nucifera L.) à la Station Marc Delorme de 2004 à 2013. Mémoire de Brevet de Technicien Supérieur, Groupe Loko; 2014. p. 36.
4. Dassé DAF. Bilan de la production sur quelques parcelles de la Station Marc Delorme de 2003 à 2010. Mémoire pour l'obtention du diplôme de Brevet de Technicien Supérieur (BTS). Option: Agronomie Tropicale; 2012. p. 29

5. Issali AE, Lékadou TT, Nguessan AEB, et al. Effect of fruit set on fructification of coconut tall ecotypes for production of hybrid seednuts in Côte d'Ivoire. African Crop Science Journal. 2013;21(4):303-310.

6. Tan CL, Furtek DB. Development of an in vitro regeneration system for Theobroma cacao from mature tissues. Plant Science. 2003;164(3):407-412.

7. Allou D. Etude de la répartition de la production annuelle chez le palmier à huile (Elaeis guinensis Jacq.): analyse de quelques caractères de production. Mémoire soutenu à l'Université de Cocody-Abidjan, Côte d'Ivoire pour l'obtention du DEA; 1997. p. 32.

8. Issali AE. Climate, phenology, genetics and embryogenesis in Theobroma cacao L. Lambert Academic Publishing (LAP), doctoral dissertation defended at Cocody-Abidjan University, Côte d'Ivoire; 2012. p. 108-109. 